\section{Trophy hunting: Broaden the debate}

In their Letter "Trophy hunting bans imperil biodiversity" (30 August, p. 874), A. Dickman et al. argue against trophy hunting bans, but the bans they mention are neither blanket nor hunting bans. France only suspended lion trophy imports, whereas Australia and The Netherlands banned import permits for trophies of several species (1) but other trophies continue to be collected worldwide and domestically. Indeed, a ban on the import of a trophy into a nation does not constitute a ban on hunting by its nationals; Dickman et al. confound the two, which is disingenuous and raises the question of whether hunting is a sport or a form of commodity acquisition (2).

International movement of trophies is regulated under the Convention on International Trade in Endangered Species (CITES), governed by member states. Unless there is evidence of trade threatening the survival of a species, sovereign states can allow hunting and export trophies, but potential importing states also have sovereignty over their response to concerns of their constituencies and have the right to implement what CITES calls "stricter domestic measures" (3). Debates around this have been politicized, which typically happens when scientific data are too inconclusive to guide policy formulation (3).

Dickman et al. misrepresent the responsibility of importing states over hunting policy; ironically, they may stimulate blanket bans by arguing against opt-outs for some countries for certain species. Moreover, they fail to mention that where hunting zones are protected areas recognized by civil law, they would remain so. In addition, habitat in hunting zones is often not effectively protected, and the collapse of trophy hunting observed in certain areas is not due to trade bans but to a failing balance of costs and benefits $(4,5)$. Trophy hunting is neither the main threat to nor the main opportunity for wildlife conservation, and we encourage a broader debate.

$$
\begin{array}{r}
\text { Hans Bauer }^{1 *} \text {, Bertrand Chardonnet }{ }^{2}, \text { Mark } \\
\text { Jones }^{3} \text {, Claudio Sillero-Zubiri } i^{1,3}
\end{array}
$$

${ }^{1}$ Wildlife Conservation Research Unit, Zoology, University of Oxford. Tubney OX13 5QL, UK. '2African Protected Areas and Wildlife, 92210 Saint Cloud France. ${ }^{3}$ Born Free Foundation, Horsham, RH12 4QP,

*Corresponding author. Email: hans.bauer@zoo.ox.ac.uk

REFERENCES AND NOTES

1. E. Ares, "Trophy hunting," Briefing Paper 7908 (House of Commons Library, London, UK, 2019).

2.C. Batavia et al., Conserv. Lett. 12, e12565 (2019).

3.H. Bauer, K. Nowell, C. Sillero-Zubiri, D. W. Macdonald, Conserv. Lett. 11, e12444 (2018).

4.H. Bauer et al., PLOS One 12, e0173691 (2017).

5.B. Chardonnet, "Africa is changing: Should its protected areas evolve? Reconfiguring the protected areas in Africa" (IUCN, 2019).

\section{COMPETING INTERESTS}

H.B. receives funding from or is a member of University of $0 \mathrm{x}$ ford, Born Free Foundation, IUCN Cat Specialist group, IUCN Save Our Species, Wildlife Conservation Network, National Geographic, U.S. Fish and Wildlife Service, Leo Foundation, GIZ (German Technical Development Cooperation), and Leipzig Zoo. B.C. receives funding from or is a member of African Union/IBAR, IUCN, GIZ (German Technical Development Cooperation), KfW (German Financial Cooperation), Afrique Nature International, Ecole Inter-Etats des Sciences et Médecine Veterinaire de Dakar (EISMV)/University of Minnesota, African Wildlife Foundation, OIE-World Organization for Animal Health, and AFD (French Agency for Development). M.J. receives funding from the Born Free Foundation. C.S.-Z. receives funding from or is a member of University of Oxford, University of Vermont, Born Free Foundation, Wildlife Consenvation Network, Fondation Segre, Conservation International Critical Ecosystem Partnership Fund, African Wildlife Foundation, IUCN Save Our Species, National Geographic, U.S. Fish and Wildlife Service, IUCN Canid Specialist group, IUCN Cat Specialist group, IUCN Wildlife Health Specialist group, IUCN Human Wildlife Conflict Task Force, and Environmental Resources Management Peru.

10.1126/science.aaz4036 